\title{
The Pulse of Thought: Hemodynamics of the Brain and Mind
}

\author{
UEBEIK DEN
}

\section{KREISLAUF DES BLUTES}

IXI

\section{MENSCHLICHEN GEIIRN.}

\author{
UNTERSUCHUNGEN \\ vos \\ A. MOSSO,

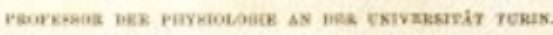

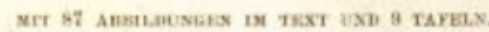

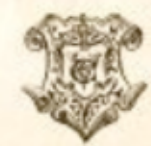

LEIPZIG,

VERI.AG VON VEIT \& COMP

$18 \times 1$.

42

II. Beschreibung der Apporate sur Aufzeichuming des Pulses.

Da bei Bertino die im Durchmesser $20 \mathrm{~mm}$ haltende Schïdel-

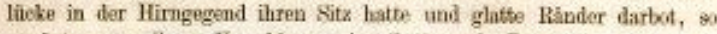
senugte es zu ilurem Verschlnsse, eine Guttaperoha-Platte aufzulegen, die in ibrer Mitte mit eimem Glasrohre rersehen war, welches die Iaft in iler

Vig. 1.

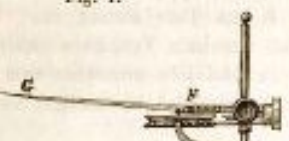

$+$
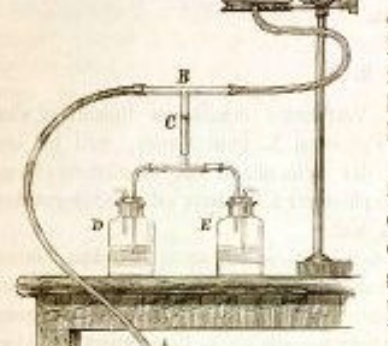

ris

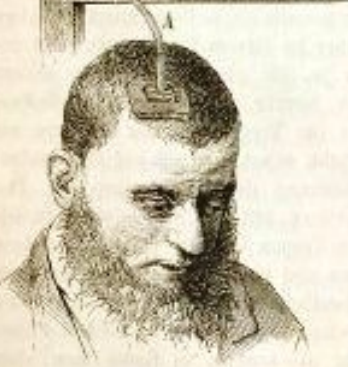

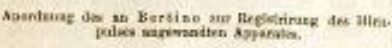
olez sonstige Manipulationen, die allesien graphischen Vorrichtungen alteriven, vornelmmen darf, weil man sonst speiter, renn das Volumen des Gebirnes vieder abnimunt, nieht mehr die tursprimglivhen Bodingungen des Versuehes herstellen kaun.

Tm dicsen Cbelstand zu vermeiden and die Hirnhewegungen unter
$\mathrm{T}$

he mapping of the human brain through regional changes in blood flow has provided psychiatry and allied neurosciences with extraordinary opportunities to explore the relation between mind and brain. This paradigm lies at the core of contemporary functional neuroanatomy and retains unprecedented potential for refining our understanding of neuropsychiatric diseases. However, the first intuition of the principle that has proved foundational for the entire field of brain imaging was almost serendipitous and dates back to 130 years ago. Angelo Mosso (1846-1910), an Italian physiologist working in Turin, explicitly formulated it in 1881 in his monograph Ueber den Kreislauf des Blutes im menschlichen Gehirn (About the Circulation of the Blood in the Human Brain) (1).

Mosso was studying the physiological concomitants of various mental states; in particular, he had started recording changes in blood circulation during laboratory-generated emotions. One of his patients, Michele Bertino, was a 37-year-old man who experienced a traumatic injury and was left with only a thin layer of skin covering a gap in his skull. While assessing Bertino with a special sphygmograph (a registering apparatus measuring in vivo brain volume changes, which were interpreted as measurements of brain circulation; see figure), Mosso noticed a sudden increase in pulsations over the cortex when the church bells rang at noon. He then asked Bertino if he felt that he should have said his midday prayers, and when Bertino answered in the positive, the pulsations increased again. Intrigued by that, almost performing a cognitive activation task ante litteram, Mosso asked him to multiply 8 by 12 . Once again the sphygmograph recorded an increase in the pulsations, both when the question was asked and when Bertino replied, "96." From this observation Mosso concluded that changes in circulation of the brain were related to mental activity.

The topicality of such intuition was acknowledged a decade later by William James, in his two-volume classic on the principles of psychology (2), published in 1890:

The best proof of the immediate afflux of blood to the brain during mental activity is due to Mosso's observations.... By means of apparatus described in his book, this physiologist was enabled to let the brain-pulse record itself directly by a tracing. The intracranial blood-pressure rose immediately whenever the subject was spoken to, or when he began to think 
actively, as in solving a problem in mental arithmetic. Mosso gives in his work a large number of reproductions of tracings which show the instantaneity of the change of blood-supply, whenever the mental activity was quickened by any cause whatever, intellectual or emotional. (2, vol I, pp. 97-99)

In the same year, Charles Roy and Charles Sherrington reformulated Mosso's original observation as an intrinsic homeostatic mechanism: "The brain possesses an intrinsic mechanism by which its vascular supply can be varied locally in correspondence with local variations of functional activity" (3).

\section{References}

1. Mosso A: Ueber den Kreislauf des Blutes im menschlichen Gehirn: Untersuchungen. Leipzig, Germany, Verlag von Veit, 1881
2. James W: The Principles of Psychology, vols I, II. New York, Henry Holt, 1890

3. Roy CS, Sherrington CS: On the regulation of the blood supply of the brain. J Physiol 1890; 11:85-108

ANDREA RABALLO, M.D., Ph.D. MATTEO CELLA, PH.D. ANTONIO PRETI, M.D.

Address correspondence to Dr. Raballo (anr@hum.ku.dk or andrea. raballo@libero.it).Photographed pages are shown with the permission of the Max Planck Institute for the History of Science. Image accepted for publication June 2011 (doi: 10.1176/appi.ajp.2011.11060913).

The authors thank Torinoscienza (http://www.torinoscienza.it) and European Cultural Heritage Online (http://echo.mpiwg-berlin.mpg.de/ home) for support in retrieving the iconographic sources. 